\title{
UC.77
}

Reporting Date: January 1976

Issued: May 1976

\section{Behavior of LASL-Made Graphite, ZrC, and ZrC-Containing Coated Particles in Irradiation Tests HT-28 and HT-29}

by

R. D. Reiswig

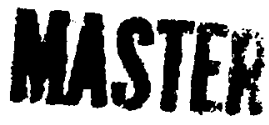

P. Wagner

C. M. Hollabaugh

R. W. White

J. A. O'Rourke

K. V. Davidson

D. H. Schell 
This work was partly supported by the US Energy Research and Development Aơmiristration, Division of Nuclear Research and Applications.

Printed in the Unitud States of America. Ayailable from

National Technical Information Service

U.S. Department of Commerce

5285 Port Royal Road

Springfield, VA 22161

Price: Printed Copy \$3.50 Microficha \$2.25

Thin ruport wae propared as en scroust of wett ponewed

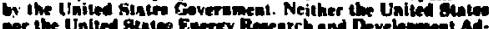

mor the United gturce Berty Reventh and Develogmont Ad-

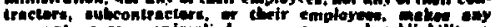

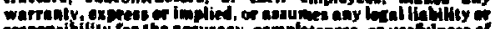

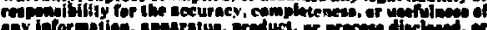

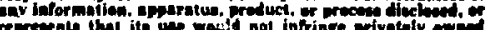

rithita. 
BEHAVIOR OF LASL-MADE GRAPHITE, ZrC, AND ZrC-CONTAINING COATED PARTICLES IN IRRADIATION TESTS HT-28 AND HT-29

\author{
by
}

R. D. Reiswig, P. Wagner, C. M. Hollabaugh, R. W. White,

J. A. O'Rourke, K. V. Davidson, and D. H. Schell

\begin{abstract}
Three types of materials, extruded graphite, hot-pressed ZrC, and particles with $\mathrm{ZrC}$ coatings, were irradiated in Oak Ridge National Laboratory High Fluence Isotope Reactor Irradiation tests HT-28 and HT-29. The ZrC seemed unaffected. The graphite changed in dimensions, $x$-ray diffraction parameters, and thermal conductivity. The four types of coated particles tested all resisted the irradiation well, except one set of particles with double-graded $\mathrm{C}-\mathrm{ZrC}-\mathrm{C}$ coats. Overall, the results were considered encouraging for use of $\mathrm{ZrC}$ and extruded graphite fuel matrices.
\end{abstract}

\section{INTRODUCTION}

Materials of interest for advanced fuels work at Los Alamos Scientific Laboratory (LASL) have been tested in the High-Fluence Isotope Reactor (HFIR) in experiments HT-28 and HT-29.1 This report summarizes the materials tested and the results of the postirradiation examination.

The High Temperature Fuels Technology for Nuclear Process Heat program at LASL is directed toward identifying nuclear fuels that can withstand higher processing temperatures and operate at nigher temperatures in gas-cooled reactors than fuels now in use. The rationale and technology developed during the program have been described in several publications. ${ }^{2 \cdot 5}$

The first reactor tests of LASL-made materials were run in Oak Ridge National Laboratory (ORNL) HFIR6 experiments HT-28 and HT-29. These tests were made to provide fast-neutron irradiation stability data on the materials intended for use in the LASL program. Because the information sought was preliminary and the tests were basically screening tests, the irradiations were performed in the HFIR target position, HT. Hot-pressed ZrC. extruded graphite, and coated particles with inert kernels were irradiated. The postirradiation examination results for each type of material are discussed separately.

\section{ZIRCONIUM CARBIDE}

The $\mathrm{ZrC}$ samples were made by hot pressing the powdered caibides at $3000 \mathrm{~K}$ and $100-\mathrm{MN} / \mathrm{cm}^{2}$ pressure using a graphite die. The billets were then repurified by heating in vacuum. Two samples were irradiated in HT-28 as follows.

In capsule position 1-A at $900^{\circ} \mathrm{C}, 4.3 \times 10^{21} \mathrm{n} \mathrm{cm}^{-2}$ (E $>0.18 \mathrm{MeV}$ ),

In capsule position $14-\mathrm{A}$ at $1250^{\circ} \mathrm{C}, 7.7 \times 10^{21} \mathrm{n}$ $\mathrm{cm}^{-2}(\mathrm{E}>0.18 \mathrm{MeV})$.

This material was contaminated and was not returned to LASL. ORNL reported no observable damage or dimensional changes. 


\section{GRAPHITE}

Extruded graphites heat treated at 1800 and $2200^{\circ} \mathrm{C}$ were irradiated in $\mathrm{HT}-28$. Lot 5508-AA was rnade from 85 parts M-3 graphite flour and 15 parts Thermax with $0.2 \mathrm{~g} / \mathrm{cm}^{3}$ of wood flour added. The green mix was made using Varcum, a polyfurfuryl ailcohol binder, and was extruded through a 12.7mm- (1/2-in.-) diam die. Lot 5508-AA-2 was given a final heat treatment at $180 n^{\circ} \mathrm{C}$; these samples were $2.5 \mathrm{~mm}$ thick. Lot 5508-AA-2-3 was given a final heat treatment at $2200^{\circ} \mathrm{C}$; these samples were $10 \mathrm{~mm}$ in diameter by $2.5 \mathrm{~mm}$ thick. The nominal density of this extrusion lot was $1.76 \mathrm{~g} / \mathrm{cm}^{3}$.

The dimensional changes in the graphite are listed in Table I. Table II lists x-ray diffraction parameters measured before and after the irradiation. There were no observable chanises in the graphite microstructure, and no cracks or porosity growth were noted. Figure 1 show's the $5508-\mathrm{AA}-2-3\left(2200^{\circ} \mathrm{C}\right.$ heat treatment) graphite as-prepared and after irradiation.

Changes in thermal conductivity, $\lambda$, of the two extruded graphites due to irradiation in the HT-29 test have been determined. Thermal diffusivities, $\alpha$, were ineasured parallel to the extrusion axis at $300 \mathrm{~K}$ on archival and irradiated (at $900^{\circ} \mathrm{C}$ ) samples of hoth graphites. Thermal conductivities were calculated using

$\lambda=\alpha \rho \mathrm{C}_{\mathrm{p}}$.

Postirradiation densities, $\rho$, were computed from original densities and dimensional changes after irradiation; the heat capacity of graphite was used for $C_{p}$.

The $\lambda$ data are displayed in Fig. 2. The thermal conductivities drop off with irradiation and seem to reach saturation at about $20 \%$ of the original velue where $\lambda$ is near $15 \mathrm{~W} \mathrm{~m}^{-1} \mathrm{~K}^{-1}$. The figure also shows the advantages of higher heat treatment temperature. Recognizing that the curves have only three points, it looks as though higher $\lambda$ values resulting from the higher heat treatment temperature keep $\lambda$ at an eleveted value throughout most of the irradiation and it approaches $15 \mathrm{~W}$ $\mathrm{m}^{-1} \mathrm{~K}^{-1}$ only after full HTGR fluence is reached. Price $^{7}$ has pointed out that $\lambda$ decreases further at lower irradiation temperatures. Higher temperature irradiation tests should yield higher postirradiation thermal conductivities.

TABLE I

DIMENSIONAL CHANGES IN LASL GRAPHITES IRRADIATED IN HT-29

\begin{tabular}{|c|c|c|c|c|c|c|}
\hline Material & $\begin{array}{c}\text { Position } \\
\text { in Reactor }\end{array}$ & $\begin{array}{l}\text { Fluence } \\
\left(\mathrm{n} / \mathrm{cm}^{2}\right)\end{array}$ & $\begin{array}{c}\text { Original } \\
\text { Dimensions } \\
(\mathrm{cm})\end{array}$ & $\begin{array}{l}\text { Postirradiation } \\
\text { Dimensions } \\
\text { (cm) }\end{array}$ & $\begin{array}{c}\% \\
\text { Change }\end{array}$ & $\begin{array}{l}\text { Orientation } \\
\text { wrt c-axis }\end{array}$ \\
\hline Lot 5508-AA-? & $1 \mathrm{~A}$ & $4.8 \times 10^{21}$ & $\begin{array}{l}i=0.701 \\
w=0.706 \\
h=0.261\end{array}$ & $\begin{aligned} l & =0.683 \\
w & =0.693 \\
h & =0.255\end{aligned}$ & $\begin{array}{l}-2.5 \\
-1.8 \\
-2.0\end{array}$ & 1 \\
\hline Lot 5508 -AA-2 & 14.A & $9.7 \times 10^{21}$ & $\begin{aligned} f & =0.704 \\
w & =0.704 \\
h & =0.264\end{aligned}$ & $\begin{array}{r}l=0.714 \\
w=0.713 \\
h=0.251\end{array}$ & $\begin{array}{l}+1 \\
+1 \\
-5.3\end{array}$ & 1 \\
\hline $\begin{array}{l}\text { Lot } 5508-\mathrm{AA}-2-3 \\
2200^{\circ} \mathrm{C} \text { heat } \\
\text { treatment }\end{array}$ & $52-A$ & $4.8 \times 10^{21}$ & $\begin{aligned} \operatorname{diam} & =0.950 \\
h & =0.259\end{aligned}$ & $\begin{aligned} \operatorname{diam} & =0.940 \\
h & =0.256\end{aligned}$ & $\begin{array}{l}-2.8 \\
-1.2\end{array}$ & 1 \\
\hline $\begin{array}{l}\text { Lot } 5508-\mathrm{AA}-2-3 \\
2200^{\circ} \mathrm{C} \text { heat }\end{array}$ & 39-A & $9.7 \times 10^{21}$ & $\begin{aligned} \operatorname{diam} & =0.950 \\
\mathbf{h} & =0.258\end{aligned}$ & $\begin{array}{r}\operatorname{diam}=0.960 \\
h=0.244\end{array}$ & $\begin{array}{l}+1 \\
-5.1\end{array}$ & 1 \\
\hline
\end{tabular}

Temperature at all positions used was $900^{\circ} \mathrm{C}$. 
TABLE $\boldsymbol{n}$

X-RAY DIFFRACTION PARAMETERS OF

GRAPHTES IRRADIATED IN GT-z

\begin{tabular}{|c|c|c|c|c|c|c|c|c|c|}
\hline Material & $\begin{array}{l}\text { Poaltion } \\
\text { In Reactor }\end{array}$ & $\begin{array}{l}\text { Irrodiation } \\
\text { Temp ('C) }\end{array}$ & $\begin{array}{l}\text { Fluenceb } \\
\text { (o cm-2) }\end{array}$ & 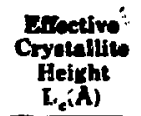 & $\begin{array}{l}\text { Entortive } \\
\operatorname{dim}_{\text {mo }}(A)\end{array}$ & $\begin{array}{c}\text { Ertective } \\
\text { (d) }\end{array}$ & $\begin{array}{l}\text { (11G)e } \\
\text { Breadth }\end{array}$ & $\begin{array}{c}\text { Becon } \\
\text { Anicotropy } \\
\text { Pector }\end{array}$ & Remarts \\
\hline \multirow[t]{2}{*}{$\begin{array}{l}8608 \mathrm{MA-2} \\
\left(1800^{\circ} \mathrm{C}\right)\end{array}$} & $\cdots$ & $\cdots$ & 0 & $\begin{array}{r}392 \\
342 \\
66\end{array}$ & $\begin{array}{l}3.362 \\
3.36 \\
3.43\end{array}$ & 2.481 & 0.43 & & $\begin{array}{l}\text { Componite } \\
\text { Crystalline componert } \\
\text { Noncrystalline component }\end{array}$ \\
\hline & $1 \cdot A$ & 800 & $4.8 \times 10^{211}$ & 183 & 3.370 & 2.450 & 0.60 & & \\
\hline$\because$ & 14-A & 900 & $8.7 \times 10^{21}$ & 95 & 3.375 & 2.458 & 0.74 & & \\
\hline \multirow[t]{3}{*}{$\begin{array}{c}5508 \mathrm{AA-2-3} \\
\left(22000^{\circ} \mathrm{C}\right)^{\circ}\end{array}$} & $\ldots$ & $\ldots$ & 0 & $\begin{array}{l}290 \\
370 \\
121\end{array}$ & $\begin{array}{l}3.363 \\
3.36 \\
3.42\end{array}$ & 2.461 & 0.43 & 1.477 & $\begin{array}{l}\text { Composite } \\
\text { Cryatalline component } \\
\text { Nonerytatline component }\end{array}$ \\
\hline & 32-A & 900 & $4.8 \times 10^{21}$ & 160 & 3.369 & 2.459 & 0.60 & & \\
\hline & 39.A & 800 & $9.7 \times 10^{22}$ & $\begin{array}{l}93 \\
\lambda\end{array}$ & 3.374 & 2.457 & 0.80 & 1.282 & \\
\hline
\end{tabular}

- Heat treatment temperature.

$\mathrm{GE}>0.18 \mathrm{MeV}$.

chereaing value in measure of increasing basal plane dieorder.

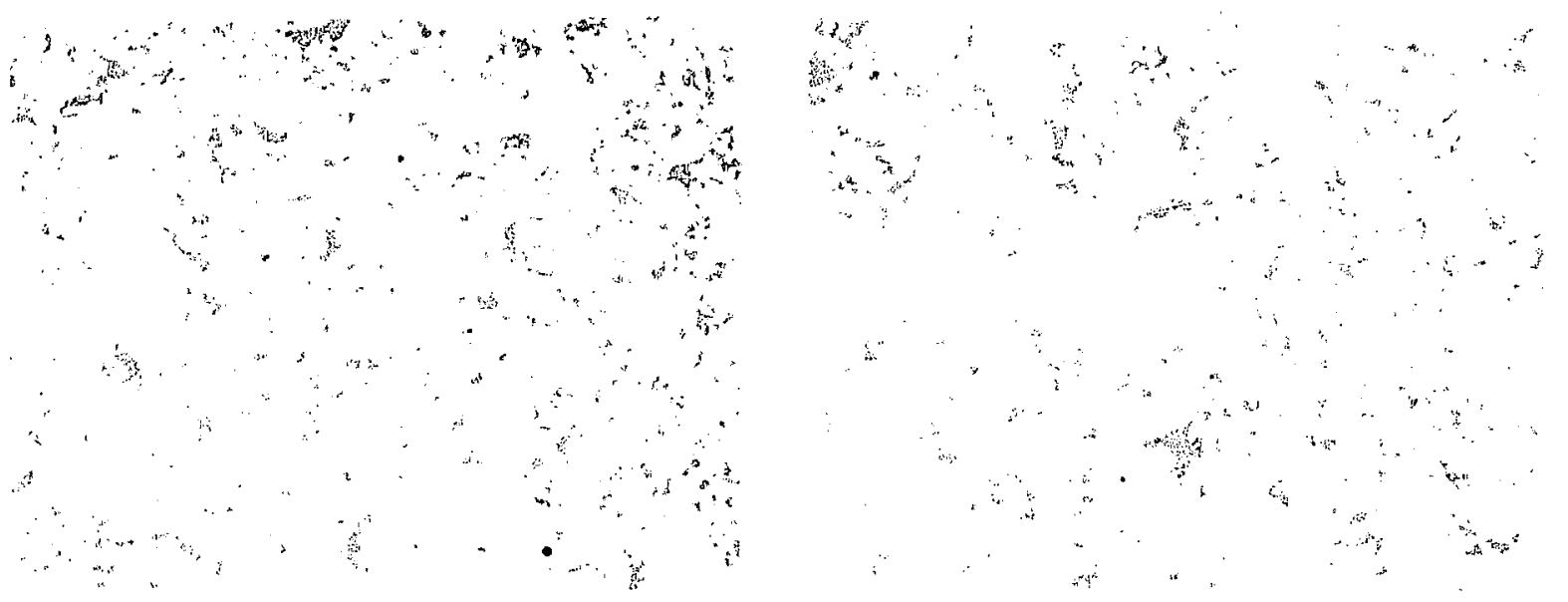

Fig. 1.

Microstructure of 5508-AA-3-2 graphite irradiated in HT-29. Left: As-prepared $\left(2200^{\circ} \mathrm{C}\right.$ heat treatment). Right: After $900^{\circ} \mathrm{C}, 9.7 \times 10^{21} \mathrm{n} \mathrm{cm}^{-21}$ irradiation. $50 \mathrm{X}$.

\section{COATED PARTICLES}

Four types of LASL-made coated particles were tested in HT-28 and HT-29. All had carbon kernels, and they were tested to determine their stability at high temperature and fluence. These particles were made as follows.
Pun 1435:

Carbon kemel with a mean diameter of $192 \mu \mathrm{m}$ $(12)^{*}$ and density of $1.48 \mathrm{~g} / \mathrm{cm}^{3}$. The buffer coat was

*Numbers in parentheses are standard deviations of the mean. 


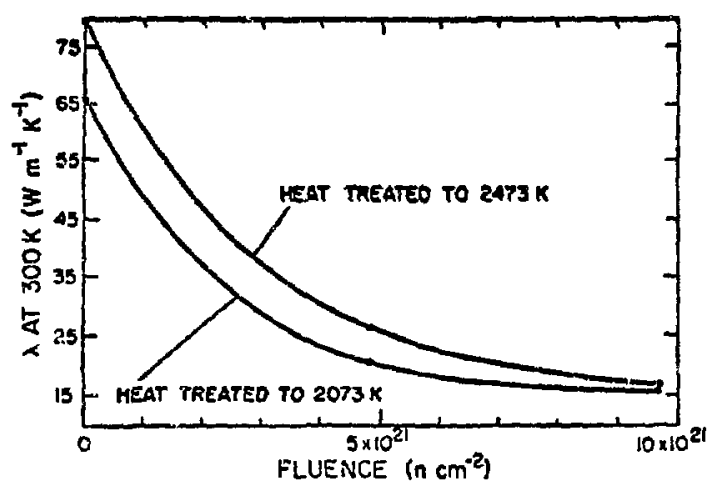

Fig. 2.

Radiation is thermal conductivity of two graphites (measured parallel to extrusion axis).

$93 \mu \mathrm{m}$ (7) thick with a density of $1.18 \mathrm{~g} / \mathrm{cm}^{3}$. It was deposited at a maximum temperature* of $1400 \mathrm{~K}$ using a $99 \% \mathrm{C}_{2} \mathrm{H}_{2}-1 \%$ Ar coating gas. The inner lowtemperature isotropic (iLTI) pyrolytic carbon coating was $28 \mu \mathrm{m}$ (3) thick with a density of 2.0 $\mathrm{g} / \mathrm{cm}^{3}$. It was deposited at a maximum temperature of $1750 \mathrm{~K}$ using a $29 \% \mathrm{C}_{3} \mathrm{H}_{6}-71 \%$ Ar coating gas. The outermost layer on these particles was $\mathrm{ZrC}, 24$ $\mu \mathrm{m}$ (2) thick with a calculated density of $6.4 \mathrm{~g} / \mathrm{cm}^{3}$ ( $\sim 97 \%$ of theoretical). It was deposited at a maximum temperature of $1725 \mathrm{~K}$ using $8.6 \% \mathrm{ZrCl}_{4}-0.6 \%$ $\mathrm{CH}_{4}-74 \% \mathrm{H}_{2}-16.8 \%$ Ar coating gas.

\section{Run 1436:}

These were TRISO particles. To some of the particles from run 1435, an outer LTI (oLTI) was added. This coating was $35 \mu \mathrm{m}(7)$ thick with a density of $1.80 \mathrm{~g} / \mathrm{cm}^{3}$. It was deposited at a maximum temperature of $1775 \mathrm{~K}$ using an $18 \% \mathrm{C}_{3} \mathrm{H}_{6}-82 \% \mathrm{Ar}$ coating, gas.

\section{Run 1450:}

These particles contained the same kernel and buffer substrate as those in runs 1435 and 1436 . They had an additional coating that started out as a pure LTI. Zirconium carbide was added, and the pyrolytic carbon content was diminished gradually until pure $\mathrm{ZrC}$ was deposited, giving a coating graded from iLTI to $\mathrm{ZrC}$. The maximum temperature was $1670 \mathrm{~K}$. The LTI was deposited from a $22 \%$ $\mathrm{C}_{3} \mathrm{H}_{6}-78 \%$ Ar gas mixture. Zirconium chloride and hydrogen were added, and the $\mathrm{C}_{: 1} \mathrm{H}_{6}$ was decreased

*There is an axial temperature gradient in the fluidized bed crating furnace. Teinperature maxima are quoted. until the outermost $\mathrm{ZrC}$ layer was deposited from a $1 \% \mathrm{C}_{3} \mathrm{H}_{6}-3 \% \mathrm{ZrCl}_{4}-15 \% \mathrm{H}_{2}-81 \%$ Ar gas mixture. The innermost part of the graded coat looks like pyrolytic carbon under the microscope. It was $18 \mu \mathrm{m}$ (3) thick; the outermost part was $22 \mu \mathrm{m}$ (4) thick.

\section{Run 1452}

These particles had the same kernel and buffer substrate used fo: runs 1435,1436 , and 1450 . Added to this was a double-graded coat that started out as pure LTI, $23 \mu \mathrm{m}$ (4) thick. It was then graded to $\mathrm{ZrC}$, a pure $\mathrm{ZrC}$ layer, and then $\mathrm{ZrC}$ graded to pure $\mathrm{LTI}$. The maximum temperature was $1670 \mathrm{~K}$, and the coats were deposited as follows.

Inner Graded Coat. Started with $22 \% \mathrm{C}_{3} \mathrm{H}_{6}-78 \%$ Ar. Added $\mathrm{ZrCl}_{4}$ and $\mathrm{H}_{2}$ and decreased $\mathrm{C}_{3} \mathrm{H}_{6}$ gradually until final gas composition was $1 \% \mathrm{C}_{3} \mathrm{H}_{6}{ }^{-}$ $4 \% \mathrm{ZrCl}_{4}-20 \% \mathrm{H}_{2}-75 \%$ Ar.

Pure $\mathrm{ZrC}$. Switched from $\mathrm{C}_{3} \mathrm{H}_{6}$ to $\mathrm{CH}_{4}$ and coated with $0.6 \% \mathrm{CH}_{4}-3.4 \% \mathrm{ZrCl}_{4}-18 \% \mathrm{H}_{2}-78 \%$ Ar gas.

Outer Graded Coat. Switched back to $\mathrm{C}_{3} \mathrm{H}_{6}$ and started coating using $1 \% \mathrm{C}_{3} \mathrm{H}_{6}-4 \% \mathrm{ZrCl}_{4}-18 \% \mathrm{H}_{2}$ $77 \%$ Ar gas mixture. Increased $\mathrm{C}_{3} \mathrm{H}_{6}$ gradually until concentration was about $8 \%$. Then switched to $21 \%$ $\mathrm{C}_{3} \mathrm{H}_{6}-79 \%$ Ar gas mixture for outermost pure LTI. The inner graded coat was $35 \mu \mathrm{m}$ (2) thick, the $\mathrm{ZrC}$ was $7 \mu \mathrm{m}(0.1)$ thick, and the outermost graded coat was $35 \mu \mathrm{m}(2)$ thick. The oLTI was $7 \mu \mathrm{m}(0.8)$ thick. All particles were heated for $3.6 \mathrm{ks}(1 \mathrm{~h})$ at $2075 \mathrm{~K}$ in vacuum as an initial preirradiation preparation.

Table III lists the particles tested, the reactor test, the capsule position, irradiation test temperature, and total fluence. Also listed is the crushing strength ratio. Metallography and crushing strength tests were run when there were enough particles. In general, the strength increased with irradiation.

The TRISO-type particles from Runs 1435 and 1436 were undamaged. Irradiated particles from Run 1435 looked no different from the as-prepared particles; however, microscopy of the outer $\mathrm{ZrC}$ coat showed evidence of chemical attack (Fig. 3). Examination of other particles from Run 1435 showed similar evidence of reaction, but to a lesser extent. We conclude qualitatively that some oxidation oc. curred at the $\mathrm{ZrC}$ surface. Whether or not other particles with $\mathrm{ZrC}$ surfaces were affected is speculative. Figures 4-6 are photomicrographs of typical nonirradiated and irradiated particles from these runs.

All the coated particles from Run 1450 survived. They are shown in Figs. 7-11. A few of the irradiated particles had small radial cracks through the outer. most $\mathrm{ZrC}$ layer. Most natable was the development 
TABLE III

IRRADIATION TEST CONDITIONS AND CRUSHING SIRENGTHS

\begin{tabular}{|c|c|c|c|c|c|}
\hline $\begin{array}{l}\text { LASL } \\
\text { Coating } \\
\text { Run No. }\end{array}$ & $\begin{array}{c}\text { Reactor } \\
\text { Test }\end{array}$ & $\begin{array}{l}\text { Capsule } \\
\text { Position }\end{array}$ & $\begin{array}{l}\text { Temp } \\
\left({ }^{\circ} \mathrm{C}\right)\end{array}$ & $\begin{array}{c}\text { Pluence } \\
\left(\mathrm{n} \mathrm{cm}^{-2}\right. \\
\left.\times 10^{21}\right)\end{array}$ & $\begin{array}{c}\text { Crushing } \\
\text { Strength } \\
\text { Ratio }\end{array}$ \\
\hline 1435 & HT-28 & ES-1 & 900 & 3.5 & 1.11 \\
\hline 1435 & HT-29 & MS-1 & 900 & 9.4 & 1.64 \\
\hline 1436 & HT-28 & ES-2 & 900 & 3.5 & 1.38 \\
\hline 1436 & HT-29 & MS-2 & 900 & 9.4 & 1.64 \\
\hline $\begin{array}{l}1450 \\
1450\end{array}$ & $\begin{array}{l}\text { HT-29 } \\
\text { HT-29 }\end{array}$ & $\begin{array}{l}\text { ES-1 } \\
\text { EL-1 }\end{array}$ & $\begin{array}{l}900 \\
900\end{array}$ & $\begin{array}{l}4.4 \\
9.0\end{array}$ & $\begin{array}{l}1.75 \\
1.67\end{array}$ \\
\hline 1450 & HT-29 & ML-1 & 900 & 10.7 & 1.82 \\
\hline 1450 & HT-28 & MS-1 & 1250 & 7.5 & 1.65 \\
\hline 1452 & HT-29 & ES-2 & 900 & 4.4 & 0.99 \\
\hline 1452 & HT-29 & EL-2 & 900 & 9.0 & $\ldots$ \\
\hline 1452 & HT-29 & ML-2 & 900 & 10.7 & $\cdots$ \\
\hline 1452 & HT-28 & MS-2 & 1250 & 7.5 & -.. \\
\hline
\end{tabular}

a Postirradiation strength/preirradiation strength.

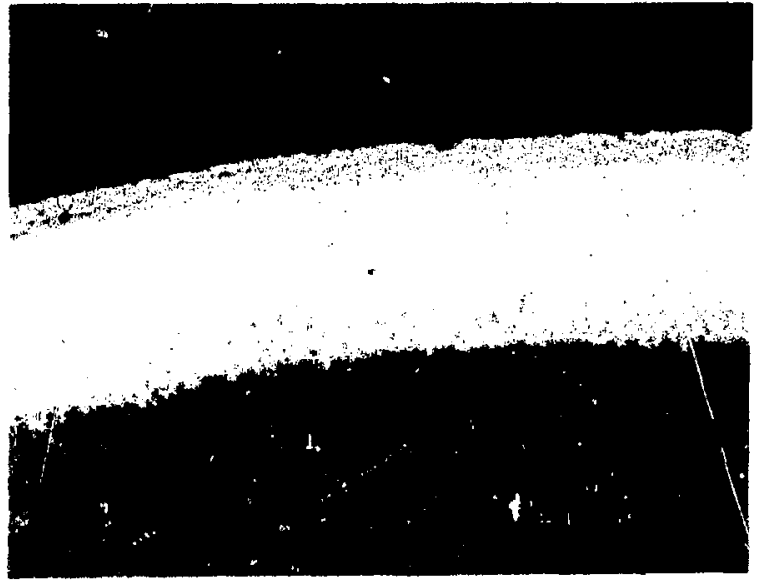

Fig. 3.

Coated particle from Run 1435 after $3.5 \times 10^{21}$ $n \mathrm{~cm}^{-2}$ at $900^{\circ} \mathrm{C}$ showing reaction at outer surface of $\mathrm{ZrC}$. $1000 \mathrm{X}$.

of preferred orientation as evidenced by the polarized light activity in the innermost layer of the graded coat. This can be seen in Figs. 8-11, photomicrographs made using polarized (polars at $\left.85^{\circ}\right)$ light. This orientation suggests a volume expansion in the carbon-rich ZrC-C layer. Because par- ticles with ZrC-doped LTI's are being irradiated in on-going tests, we will examine this hypothesis further.

Figures 12-16 show coated particles from Run 1452. Survival percentages were as follows.

After $4.4 \times 10^{21} \mathrm{n} / \mathrm{cm}^{2}$ at $900^{\circ} \mathrm{C}, 100 \%$ (Fig. 13),

After $9 \times 10^{21} \mathrm{n} / \mathrm{cm}^{2}$ at $900^{\circ} \mathrm{C}, 100 \%$ (Fig. 14). ,

After $10.7 \times 10^{21} \mathrm{n} / \mathrm{cm}^{2}$ at $900^{\circ} \mathrm{C}$, about $95 \%$ (Fig. 15),

After $7.5 \times 10^{21} \mathrm{n} / \mathrm{cm}^{2}$ at $1250^{\circ} \mathrm{C}$, about $20 \%$ (Fig. 16).

The particles in Fig. 13 show no preferred orientation under polarized light; however, many of the particles show circumferential cracks at the junction of the $\mathrm{ZrC}$ and the graded coat. The greater fluence experienced by the particles shown in Fig. 15 has generated a preferred orientation and has led to some radial cracking in the outer graded coats. Part of the outer coat of one particle was separated from the ZrC. The other particles looked goud. The particles in Fig. 16 have undergone the most dramatic changes of any tested. Only about $30 \%$ of the particles recovered had intact outer coats, $70 \%$ had no 

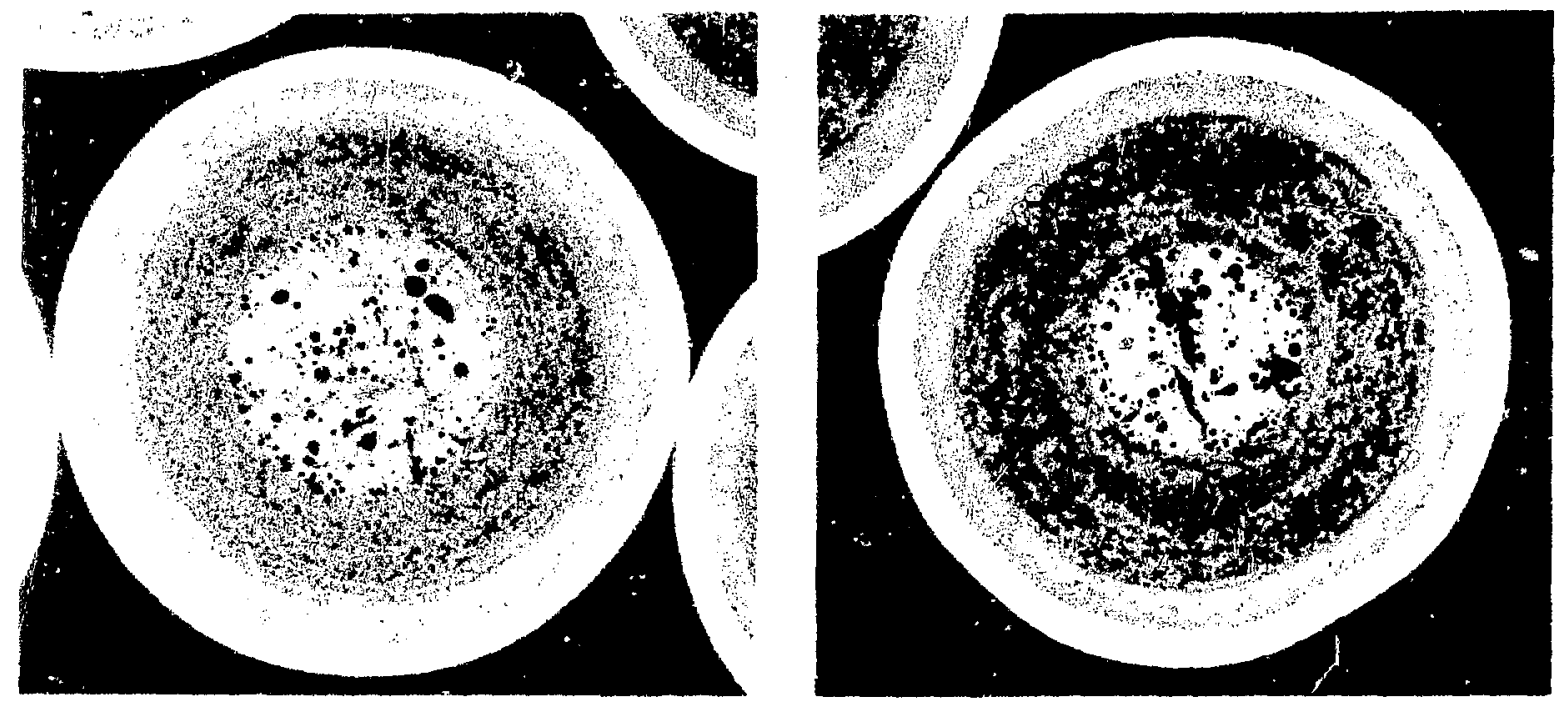

Fig. 4.

Coated particles from Run I435. Left: As prepared. Right: After $900^{\circ} \mathrm{C}, 9.4 \times 10^{21} \mathrm{n} \mathrm{cm}^{-2}$ irradiation. $150 X$.

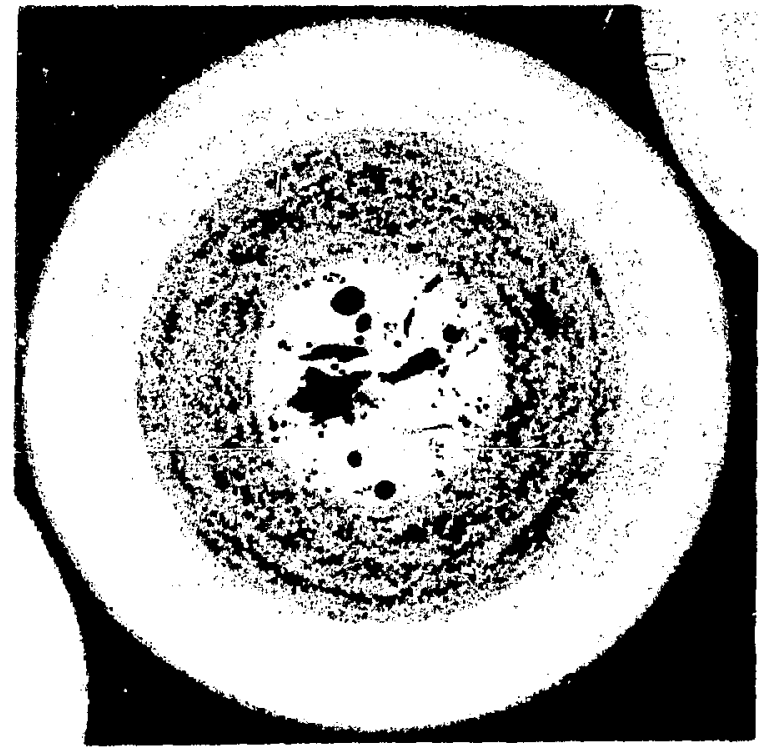

Fig. 5.

Coated particle from Run 1436 after $3.5 \times 10^{21}$ $n \mathrm{~cm}^{-2}$ at $900^{\circ} \mathrm{C}$. Bright field. $150 \mathrm{X}$.

outermost graded coat at all, and $10 \%$ had ruptured $\mathrm{ZrC}$ coats as well as broken outer coats. The intact particles showed preferred orientation in the inner and suter carbon-rich layers of the ZrC-C. As-made, these particles were like those shown in Fig. 7, the only difference being addition of the outer graded coat. The two sets of particles were in adjoining positions in the test capsule and they should have undergone very similar irradiations. Just why Run 1452 seems so different from Run 1450 in irradiation behavior is a puzzle. Perhaps further data on the particles with graded coats now being irradiated will help explain these phenomena.

\section{STATISTICS OF PARTICLE COATING THICKNESS CHANGES}

The LASL Statistical Services Group has analyzed the statistics of the measurements required to identify particle coating thickness changes caused by irradiation. The analysis took the form of tables of coefficients of variation of the mean (coating thickness), detectable changes, and number of measurements needed to detect the change. For example, in the TRISO configuration, the outer coating is $35 \mu \mathrm{m}$ thick. If the coefficient of variation of the mean is $10 \%$, 40 measu:cments would be required to identify a $1-\mu \mathrm{m}$ change in costing thickness with $95 \%$ confidence. Too few particles from HT-28 and HT-29 were obtainable to permit meaningful measurement of coating thickness changes due to irradiation. 

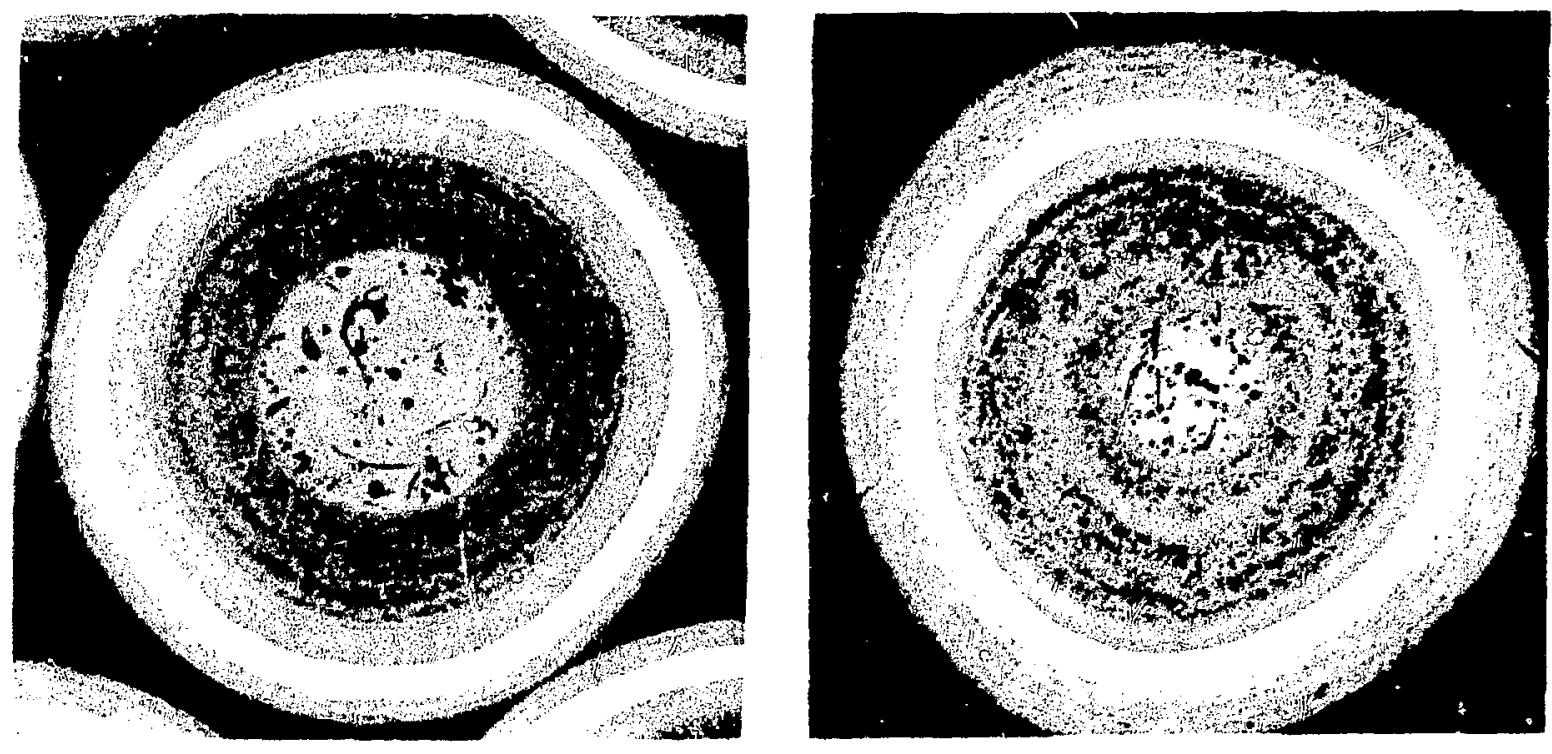

Fig. 6.

Coated particles from Run 1436. Left: As prepared. Right: After $900^{\circ} \mathrm{C}, 9.4 \times 10^{21} \mathrm{n} \mathrm{cm-2}$ irradiation. $150 \mathrm{X}$.

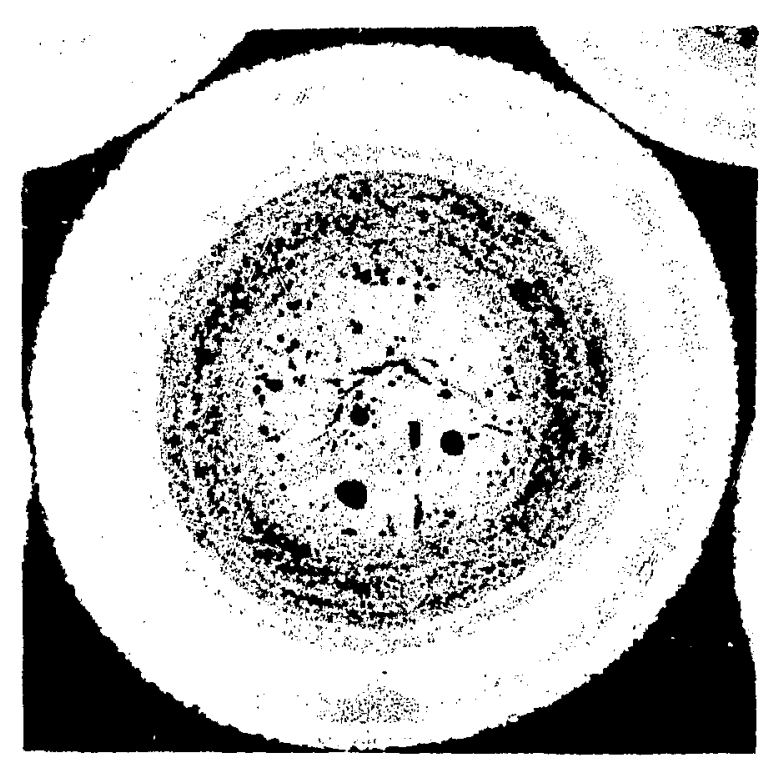

Fig. 7.

Coated particles from Run 1450. As prepared. $150 X$.

\section{ACKNOWLEDGMENTS}

The Oak Ridge National Laboratory and staff are gratefully acknowledged for help, counsel, and performance of the irradiation tests. In particular, the aid given by J. H. Coobs, W. P. Eatherly, R. L. Beatty, and E. L. Long, Jr., of the HTGR Base Program was invaluable and is especially appreciated.

\section{REFERENCES}

1. W. J. Kovacs and D. P. Harmon, "Preirradiation Report HT-28 and HT-29," General Atomic Co. report GA-A-13276 (June 1975).

2. J. D. Balcomb and P. Wagner, "Extending the Temperature Range of the HTR," Proc. BNES Intern. Conf. (London, Nov. 1974).

3. P. Wagner, C. M. Hollabaugh, and R. J. Eard, "ZrC, a Key Ingredient for High Temperature Fuels," presented at the IAEA Symposium on Gas Cooled Reactors with Emphasis on Advanced Systems, for publication in the Proceedings (Juelich, FRG, Oct. 13-17, 1975). 

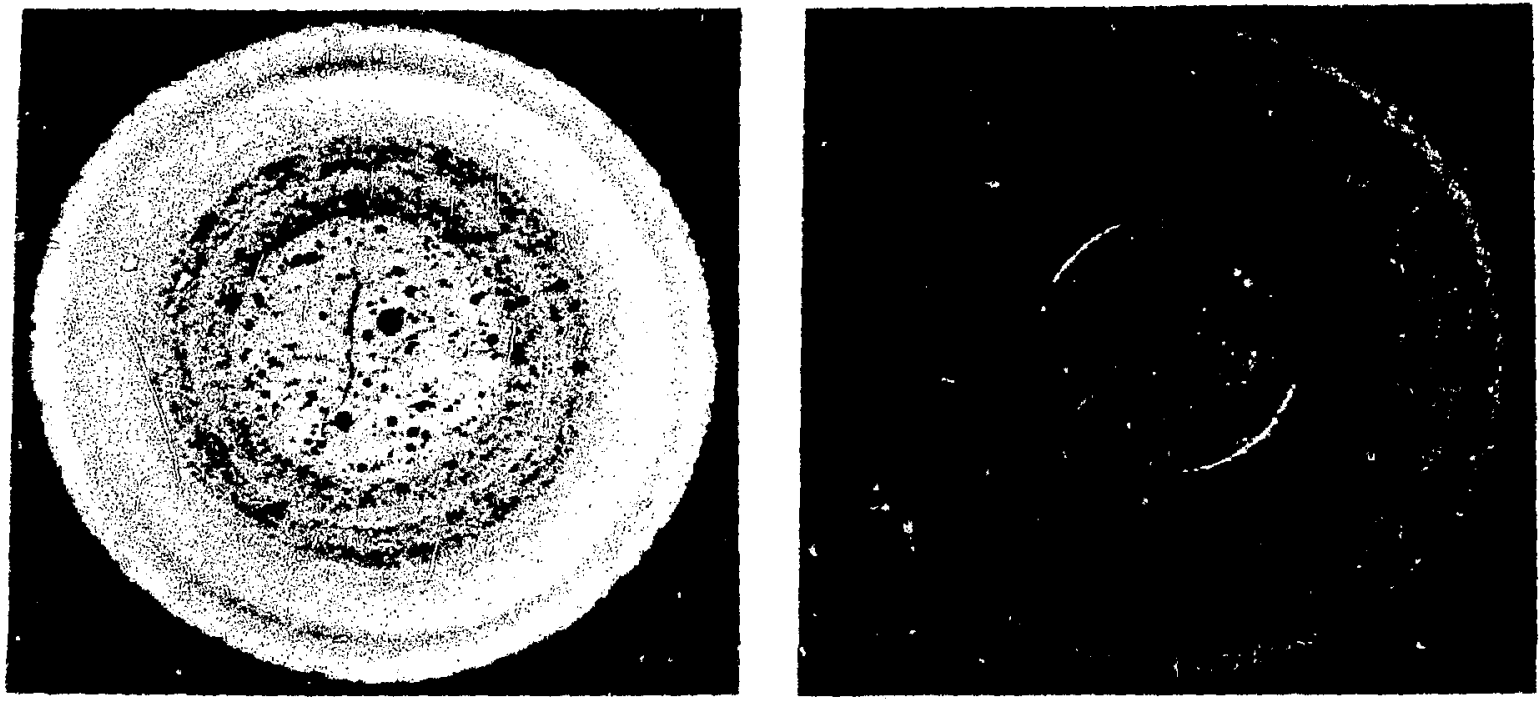

Fig. 8.

Coated particles from Run 1450 after $4.4 \times 10^{21} \mathrm{n} \mathrm{cm}^{-2}$ at $900^{\circ} \mathrm{C}$. Left: Bright field. Right: Polarizel light, preferred orientation barely detectable. $150 X$.
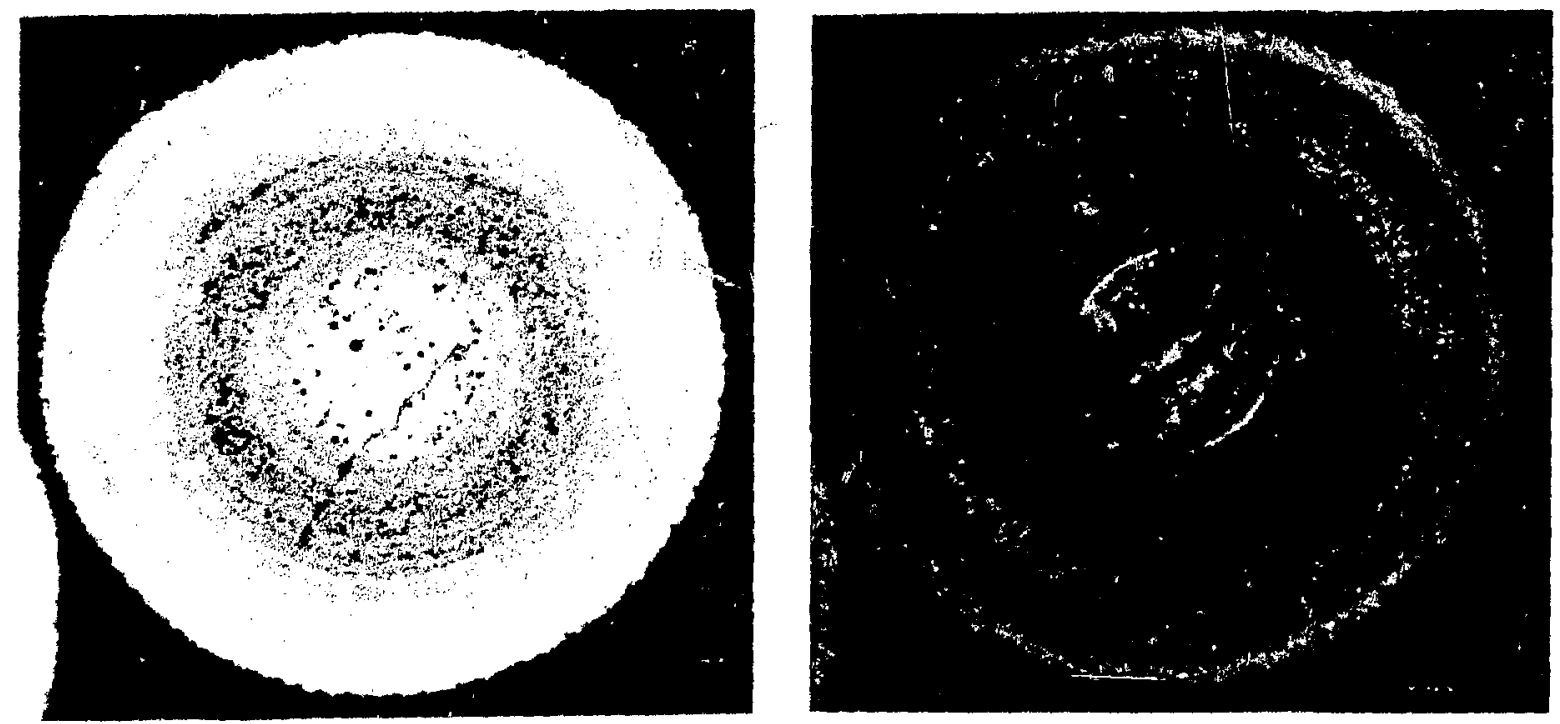

Fig. 9.

Coated particles from Run 1450 after $9.0 \times 10^{21} \mathrm{n} \mathrm{cm}^{-2}$ at $900^{\circ} \mathrm{C}$. Left: Bright field. Right: Polarized light showing preferred orientation. $150 \mathrm{X}$. 

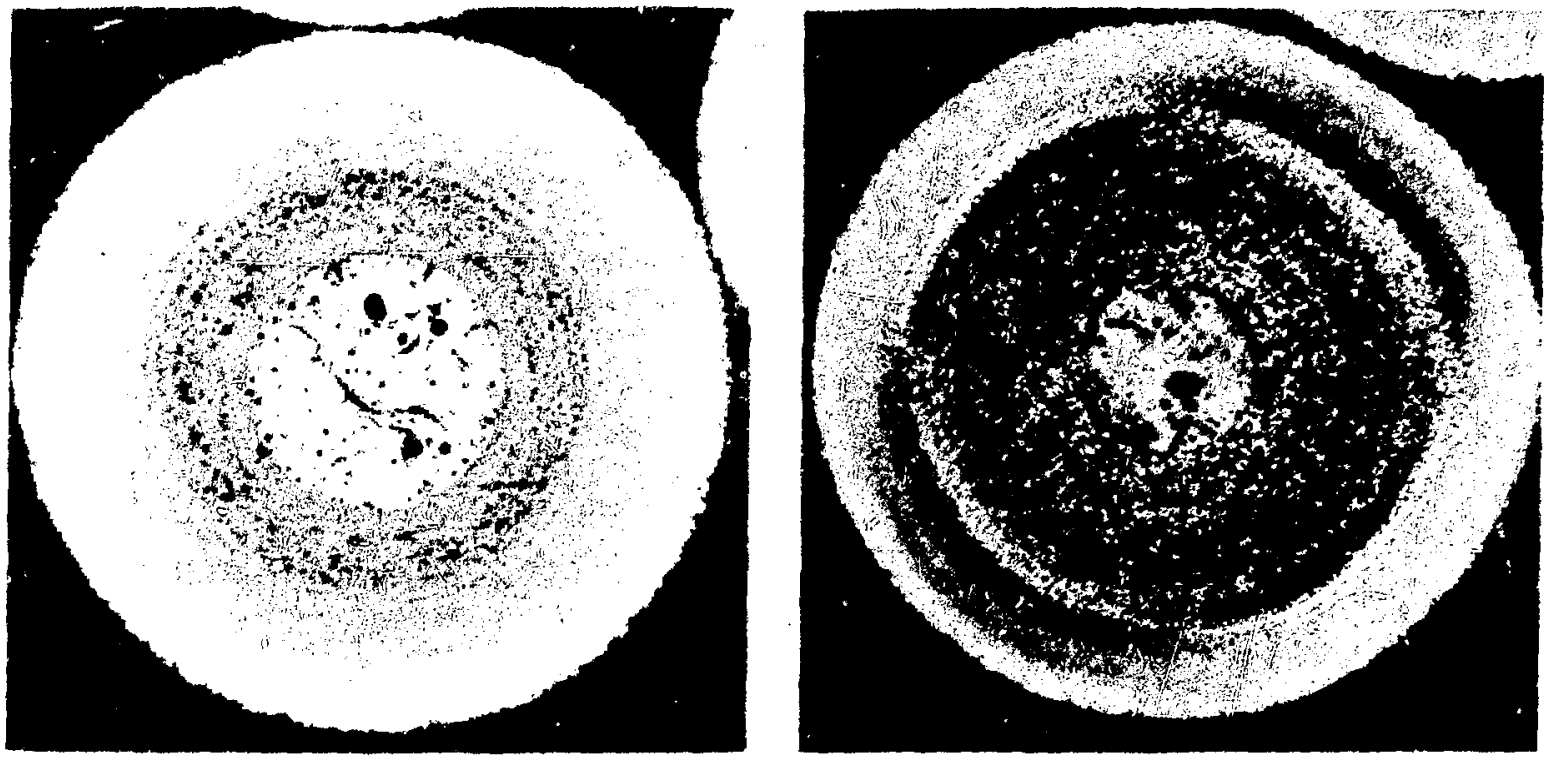

Fig. 10.

Coated particles from Run 1450 after $10.7 \times 10^{21} \mathrm{n} \mathrm{cm}^{-2}$ at $900^{\circ} \mathrm{C}$. Left: Bright field. Right: Polarized light showing preferred orientation. 150X.
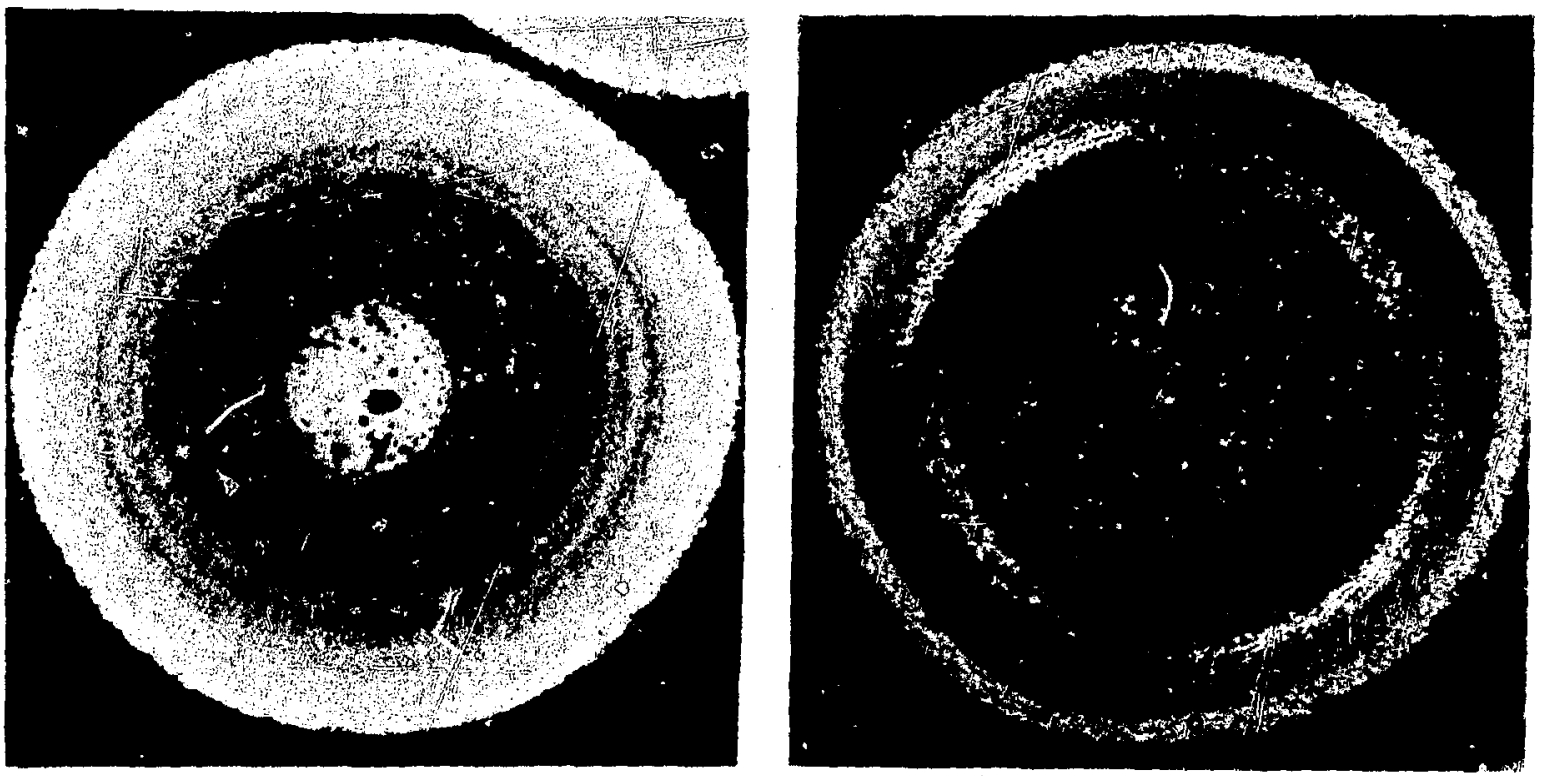

Fig. 11.

Coated particles from Run 1450 after $7.5 \times 10^{21} \mathrm{n} \mathrm{cm}^{-2}$ at $1250^{\circ} \mathrm{C}$. Left: Bright field. Right: Polarized light showing preferred orientation. $150 X$. 


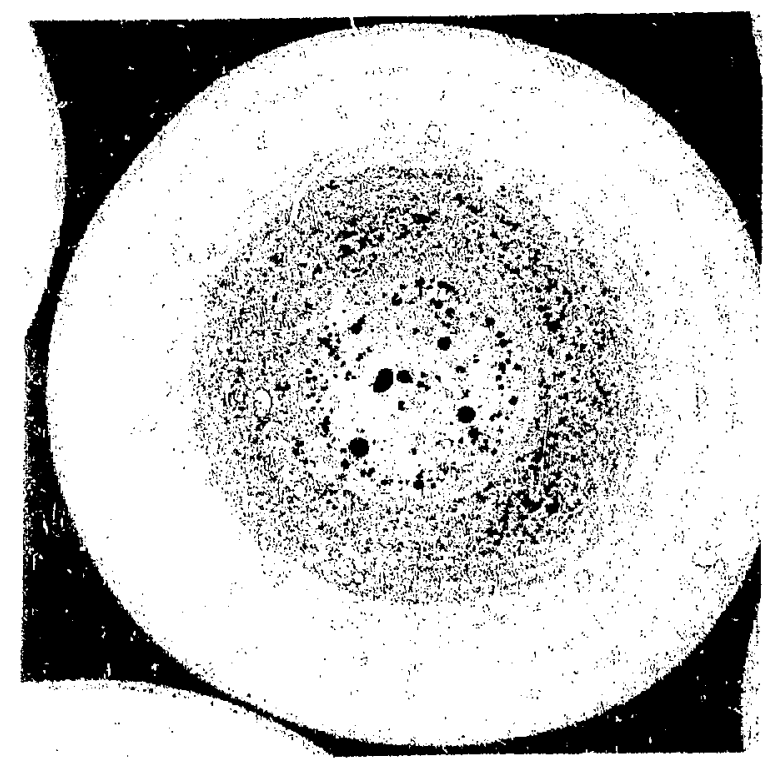

Fig. 12.

Coated particles from Run 1452 as prepared. $150 X$.
4. C. Hollabaugh, R. Reiswig, P. Wagner, R. White, and L. Wahman, "A New Method for Coating Microspheres with ZrC and ZrC-C Graded Coats," J. Nucl. Mat. 57, 325 (1975) and Los Alamos Scientific Laboratory report LA-6012 (1975).

5. P. Wagner, "The Dependence of Thermal Conductivities of Binder Residues on Heat Treatment Temperature" (submitted to Carbon and LA-6181 (1975)).

6. "The High Flux Isotope Reactor," F. T. Binford and E. N. Cramer, Eds., Vol. I and II, Oak Ridge National Laboratory report ORNL-3572 (1964).

7. R. J. Price, "Thermal Conductivity of NeutronIrradiated Reactor Graphites," Carbon 13, 201 (1975).
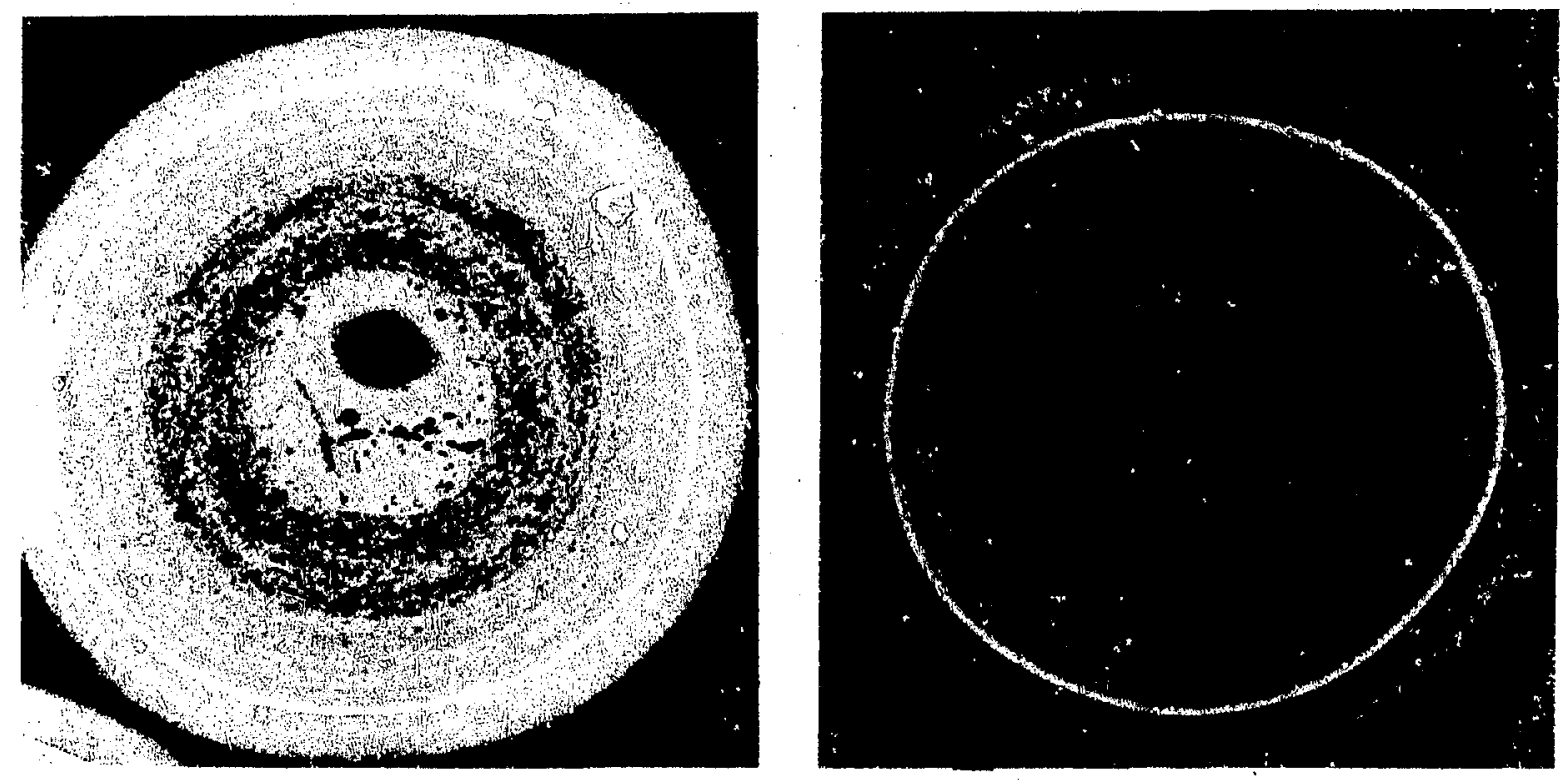

Fig. 13.

Coated particles from Run 1452 after $4.4 \times 10^{21} \mathrm{n} \mathrm{cm}^{-2}$ at $900^{\circ} \mathrm{C}$. Left: Bright field. Right: Polarized light showing preferred orientation. $150 X$. 

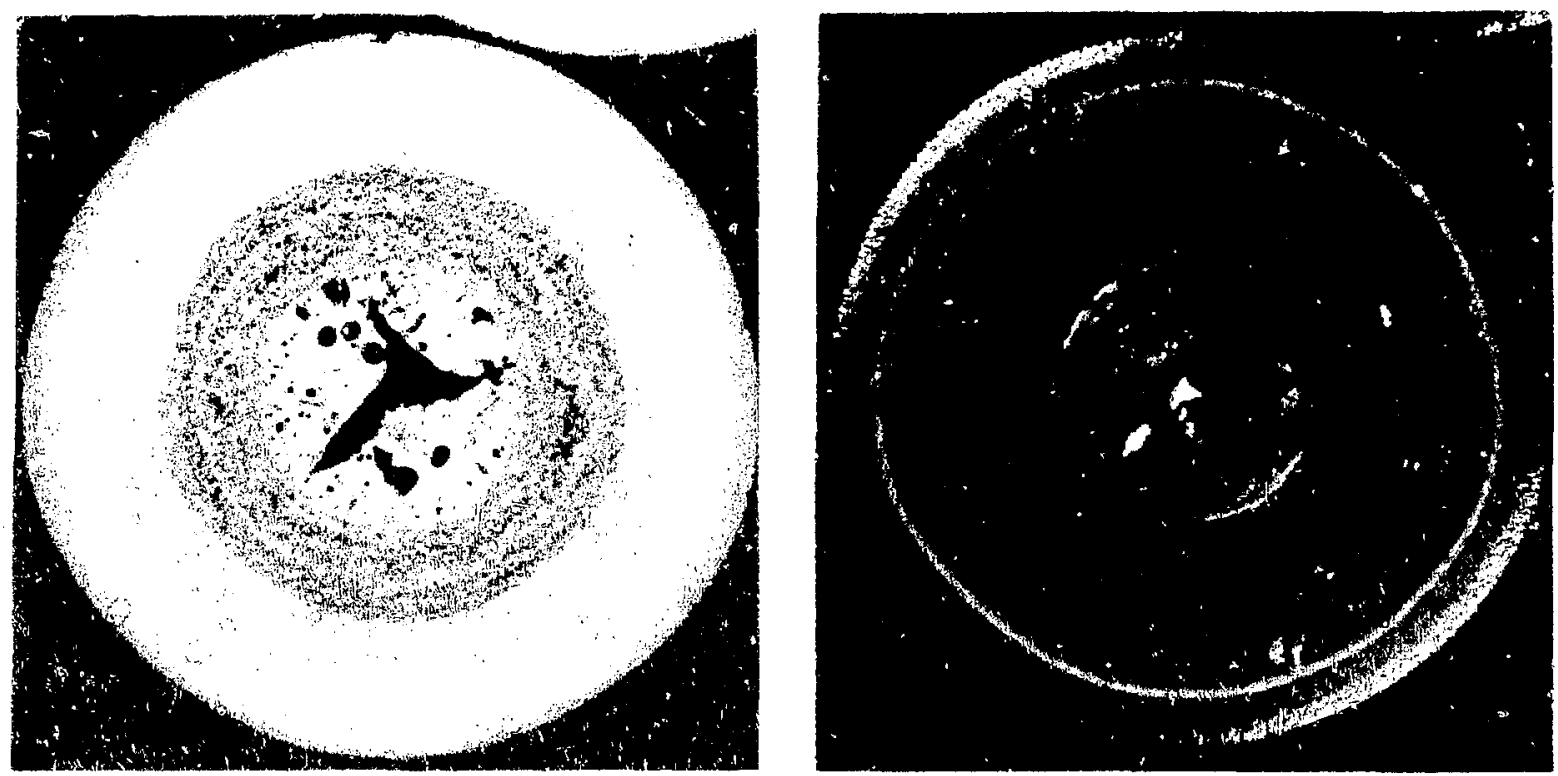

Fig. 14.

Coated particles from Run 1452 after $9.0 \times 10^{21} \mathrm{n} \mathrm{cm}^{-2}$ at $900^{\circ} \mathrm{C}$. Left: Bright field. Right: Polarized light showing preferred orientation. $150 X$.
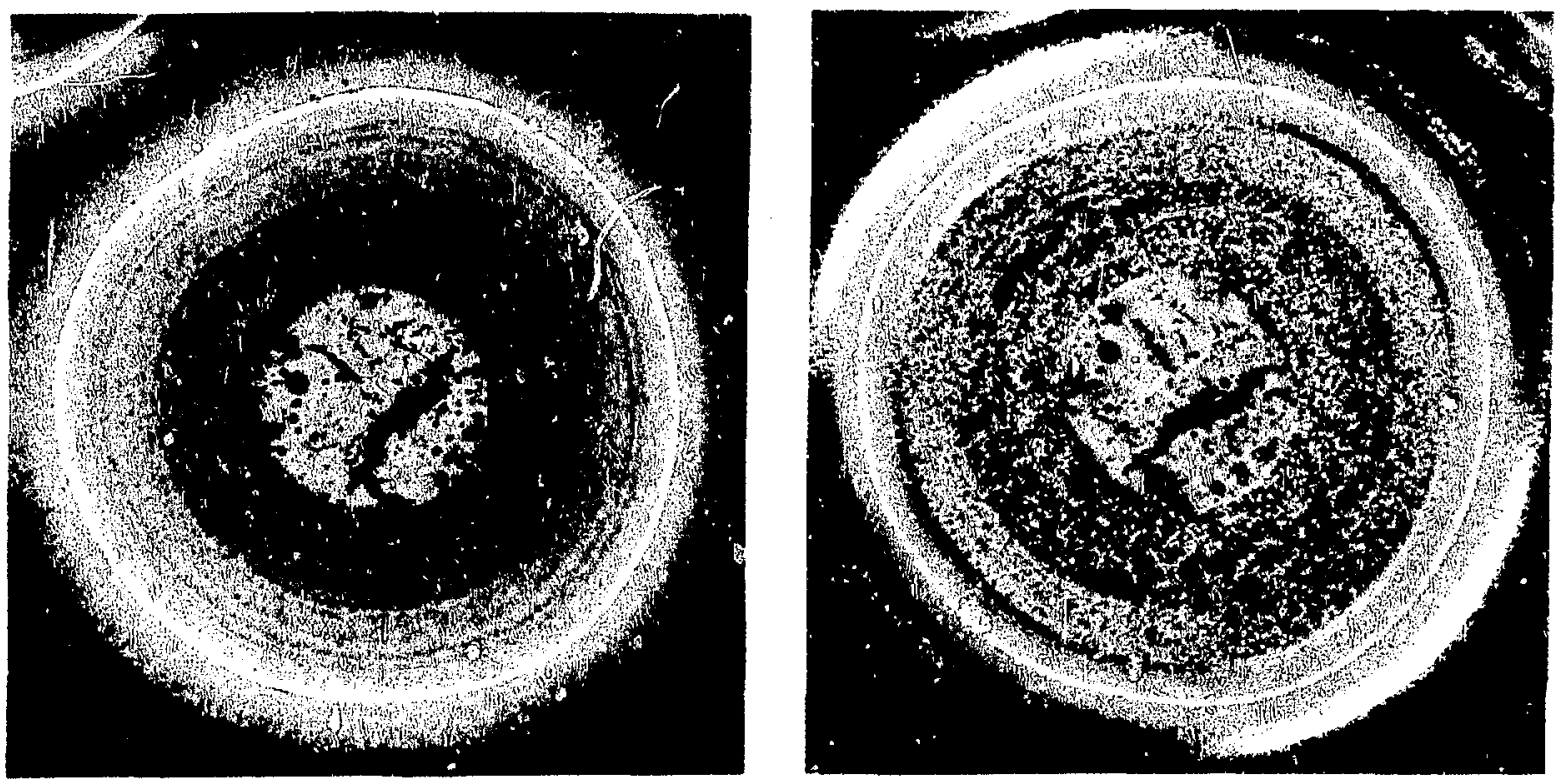

Fig. 15.

Coated particles from Run 1452 after $10.7 \times 10^{21} \mathrm{n} \mathrm{cm}^{-2}$ at $900^{\circ} \mathrm{C}$. Left: Bright field. Right: Polarized light showing preferred orientation. 150X. 


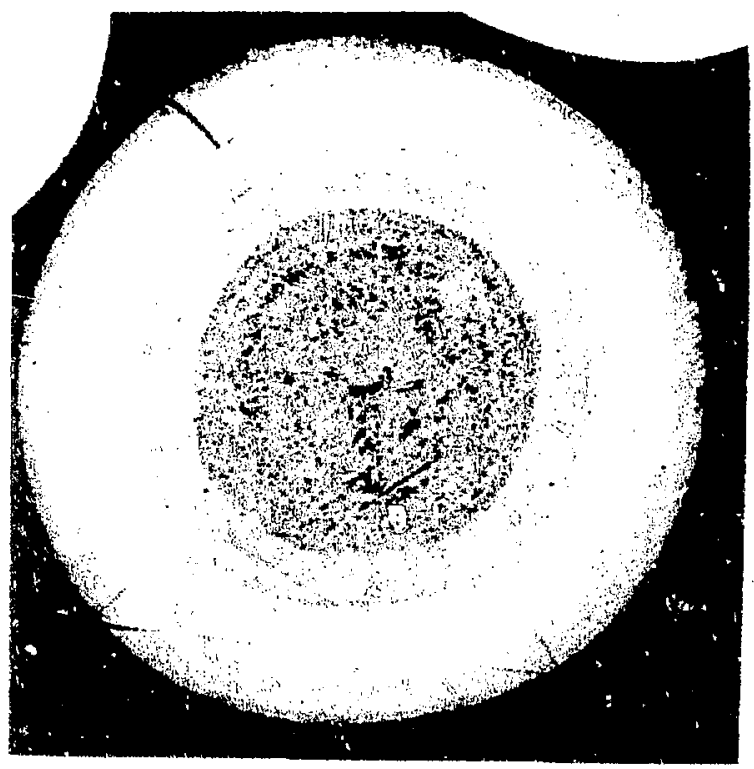

Bright field. About $20 \%$ survived test in this condition.

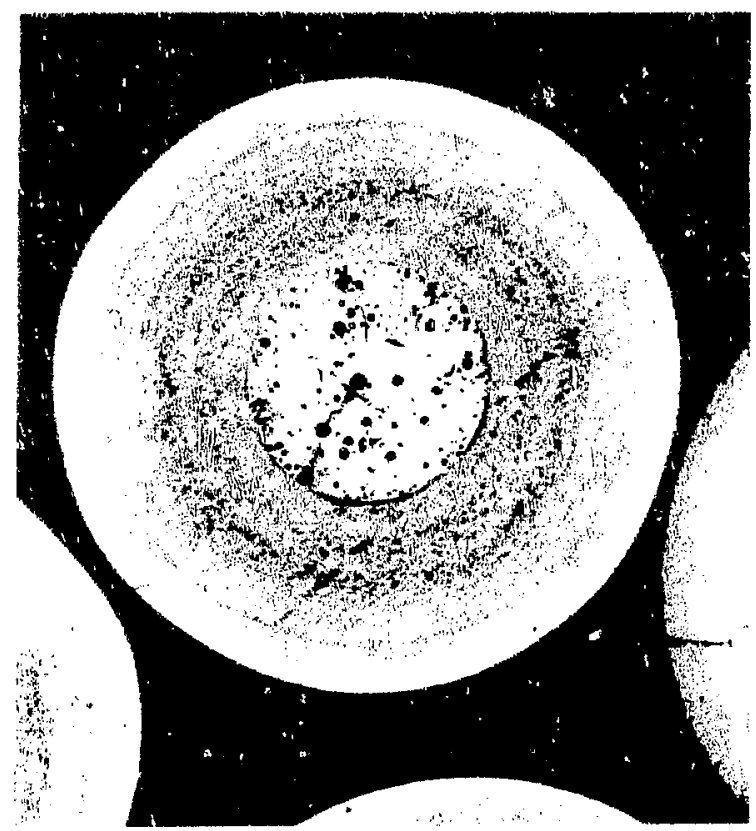

Particle with outermost coat stripped (70\%).

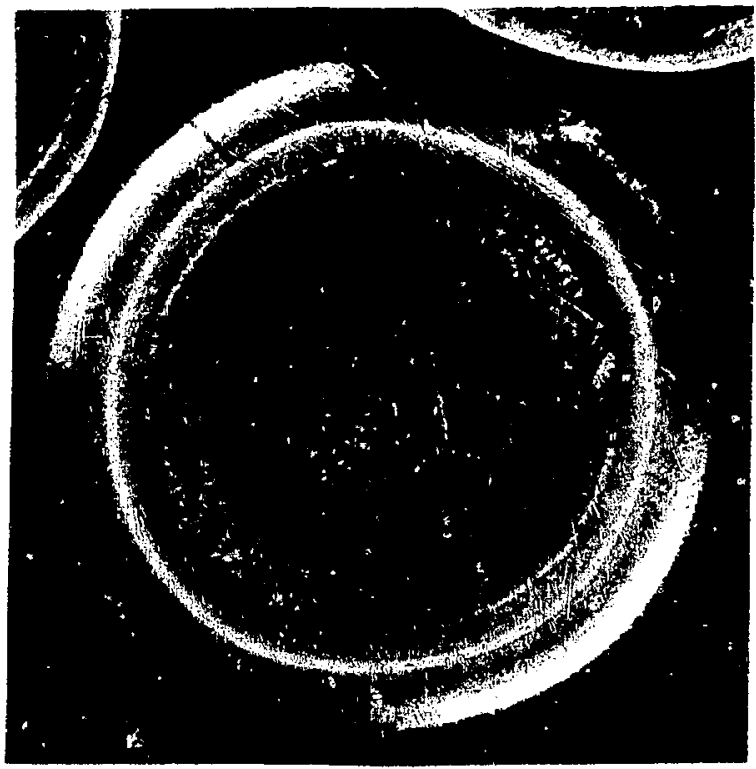

Polarized light showing preferred orientation.

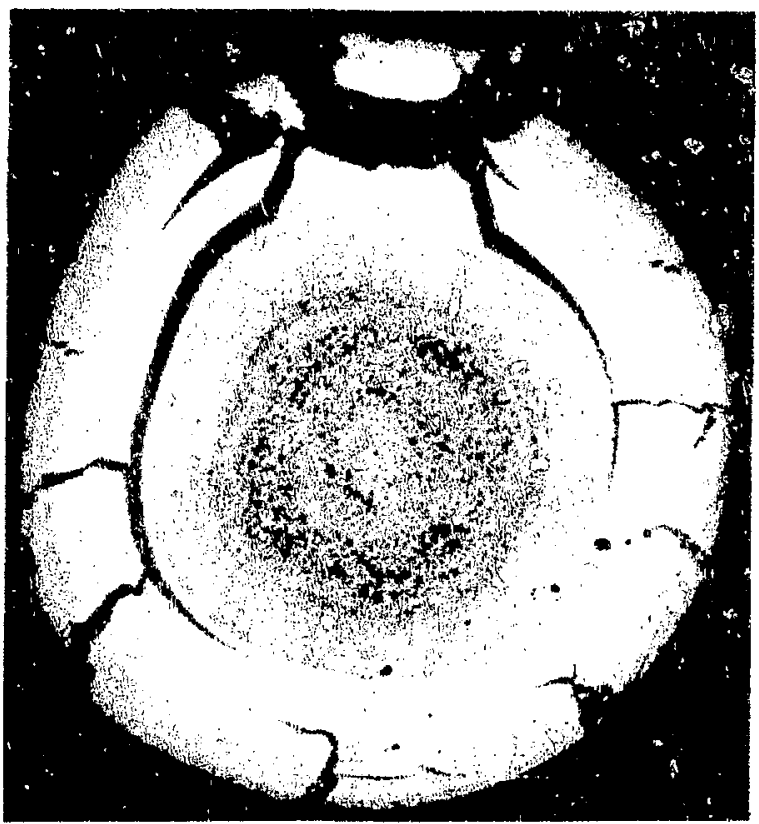

Particle with severely cracked coat (10\%).

Fig. 16.

Coated particles from Run 1452 after $7.5 \times 10^{21} \mathrm{n} \mathrm{cm}^{-2}$ at $1250^{\circ} \mathrm{C} .150 X$. 